\title{
Article \\ Effect of Recycled Aggregate Carrying Sulfate Corrosion Media on Drying and Autogenous Shrinkage of Mortar
}

\author{
Xiaohui Yan ${ }^{1,2} \oplus$, Yaogang Tian ${ }^{1, *}$, Xin Lu ${ }^{1,3}$, Jing Jiang ${ }^{1}$, Lin Qi $^{1}$ and Mengyuan Zhang ${ }^{1}$ \\ 1 School of Materials Science and Engineering, Chang'an University, Xi'an 710064, China; \\ 406779136@163.com (X.Y.); y319731590@163.com (X.L.); huiniuyihao@163.com (J.J.); \\ yxh408832356@126.com (L.Q.); y204756125@163.com (M.Z.) \\ 2 School of Henan Vocational College of Water Conservancy and Environment, Zhengzhou 450008, China \\ 3 Xi'an Highway Research Institute Co., Ltd., Xi'an 710065, China \\ * Correspondence: tianguang78@126.com
}

check for updates

Citation: Yan, X.; Tian, Y.; Lu, X.; Jiang, J.; Qi, L.; Zhang, M. Effect of Recycled Aggregate Carrying Sulfate Corrosion Media on Drying and Autogenous Shrinkage of Mortar Crystals 2021, 11, 1211. https:// doi.org/10.3390/cryst11101211

Academic Editor: Chongchong Qi

Received: 16 September 2021

Accepted: 5 October 2021

Published: 8 October 2021

Publisher's Note: MDPI stays neutral with regard to jurisdictional claims in published maps and institutional affiliations.

Copyright: (C) 2021 by the authors Licensee MDPI, Basel, Switzerland. This article is an open access article distributed under the terms and conditions of the Creative Commons Attribution (CC BY) license (https:/ / creativecommons.org/licenses/by/ $4.0 /)$.

\begin{abstract}
In this study, the effects of recycled sand (RS) carrying sulfate corrosion media on mortar drying and autogenous shrinkages were investigated. Four variables were considered, the replacement percentage of RS, water to cement (W/C) ratio, secondary cementitious material, and the corrosion concentration of RS. The test results indicated that the replacement percentage of RS was positively related to the drying and autogenous shrinkages of the mortar. The drying shrinkage of the mortar increased with an increase in the W/C ratio, while the autogenous shrinkage showed an opposite trend. The addition of fly ash (FA) had a significant inhibitory effect on the drying and autogenous shrinkages of the mortar. The drying shrinkage of the mortar was reduced, while the autogenous shrinkage was increased by adding granulated blast-furnace slag (GBFS). The addition of both FA and GBFS caused an increase in the autogenous shrinkage. As the corrosion concentration of RS increased, the drying and autogenous shrinkage values decreased slightly. The scanning electron microscopy and X-ray diffraction analysis results showed that the corrosion products formed by the reaction of sulfate ions carried by RS and cement hydration products filled the internal pores of the mortar and slowed down the shrinkage of the mortar.
\end{abstract}

Keywords: recycled fine aggregates; sulfate corrosion media; drying shrinkage; autogenous shrinkage; microstructure

\section{Introduction}

In recent decades, the utilization of construction waste has become an important issue worldwide. According to statistics from the Chinese Academy of Sciences, about 2.4 billion tons of construction waste are generated annually [1]. Consequently, relevant regulations have been promulgated to vigorously develop the classification and utilization of construction waste. Under the regulations carried out in China, various studies have been conducted on the recycling of the construction waste. The method of partially or completely replacing natural aggregates with recycled aggregates (RAs) to prepare recycled concrete has been widely regarded as an effective approach [2-5].

Generally, aggregate content is up to $70 \%$ concrete, and the influence of the aggregate on the performance of concrete is crucial. As compared with natural aggregates, RAs have a lower bulk density, higher porosity, higher water absorption, and higher crushing index [6,7], primarily due to adhered mortar, which affect the recycled concrete. Therefore, studies have investigated the optimized treatment of RAs [8-12], the source of RAs [13-16], the replacement percentage of RAs [17-20], etc. on the performance of recycled aggregate concrete (RAC). The results of studies have shown that RAs played a decisive role in the mechanical properties [21-24], durability [13,25,26], and shrinkage [25,27] of RAC.

Nevertheless, if the parent concrete is exposed to a sulfate environment, the RA would inevitably carry sulfate corrosion media. There are relatively few studies devoted to the 
effect of RA carrying sulfate corrosion media on concrete performance, with the exception of the author's earlier published studies on the diffusion of RA carrying sulfate ions in concrete [28], which lacked research on the performance of the RAC.

Shrinkage is a common phenomenon generally encountered in concrete. Shrinkage includes drying shrinkage, autogenous shrinkage, and plastic shrinkage. Drying shrinkage refers to a reduction in concrete's volume caused by water loss in low saturated air. Autogenous shrinkage is the volume change caused by the hydration of the cementitious material in concrete under constant temperature and absolute humidity. This type of shrinkage is caused by chemical action, and is the reduction in macroscopic volume caused by a reduction in capillary negative pressure and internal relative humidity caused by the hydration reaction of the cementitious material. Plastic shrinkage mainly occurs in the volume change before concrete solidification, that is, the plastic shrinkage is practically the evaporation of moisture in the initial phase, and there is no great difference between the two types of plastic and drying shrinkage. More than $80 \%$ of concrete cracks are caused by concrete shrinkage. Concrete cracking caused by shrinkage affects the safe use and aesthetics of a building, and also reduces the durability of the concrete. Therefore, it is necessary to study the shrinkage of RAC. Most studies have shown that both drying and autogenous shrinkage of recycled concrete gradually increased with an increase in the RA replacement percentage [29-32]. However, individual experiments have reached the opposite conclusion. G. Soberón [33] found that when the replacement percentages of RA were $60 \%$ and $100 \%$, the total shrinkage of the recycled concrete increased by $25 \%$ and $18 \%$, respectively. It was also found that the higher the strength of the parent concrete, the stronger the shrinkage resistance of the recycled concrete [34,35]. It could be due to the different porosity of the RA. When it is more resistant, it automatically means that it is less porous, and therefore it absorbs less water during the mixing and preparation of the concrete, and then there is a lower release of water for evaporation and, consequently, a lower shrinkage. In addition to the two factors mentioned above, the water to cement (W/C) ratio [29], FA [36,37], blast furnace slag [38], fiber [39-41], particle size of RA [42,43], etc., are also important parameters controlling concrete shrinkage. The presence of blended materials such as fly ash (FA) and granulated blast-furnace slag (GBFS) ultimately led to a significant impact on concrete shrinkage.

In this study, we aim to investigate the effect of recycled sand (RS) carrying sulfate corrosion media on drying and autogenous mortar shrinkage, in terms of the replacement percentage of RS, W/C ratio, secondary cementitious material, and the corrosion concentration of RS. Furthermore, the phase composition of the products was analyzed by X-ray diffraction (XRD), and the internal structure of the mortar and the microscopic morphology of the reaction products were observed by scanning electron microscopy (SEM).

\section{Materials and Experiment}

\subsection{Materials and Mix Proportions}

Cement (C): Portland cement (P.O42.5) (Qin lin, Xi'an, Shaanxi, China) was used in the concrete mixture and its physical properties are presented in Table 1.

Table 1. Physical properties of cement.

\begin{tabular}{|c|c|c|c|c|c|c|c|}
\hline \multirow{2}{*}{\multicolumn{2}{|c|}{$\begin{array}{l}\text { Compression } \\
\text { Strength (MPa) }\end{array}$}} & \multirow{2}{*}{\multicolumn{2}{|c|}{$\begin{array}{l}\text { Flexural Strength } \\
\text { (MPa) }\end{array}$}} & \multicolumn{2}{|c|}{ Setting Time (min) } & \multirow{3}{*}{$\begin{array}{c}\text { Specific } \\
\text { Surface } \\
\text { Area } \\
\left(\mathrm{m}^{2} / \mathrm{kg}\right)\end{array}$} & \multirow{3}{*}{$\begin{array}{c}\text { Standard } \\
\text { Consis- } \\
\text { tency } \\
(\%)\end{array}$} \\
\hline & & & & Initial & Final & & \\
\hline $3 \mathrm{~d}$ & $28 \mathrm{~d}$ & $3 d$ & $28 \mathrm{~d}$ & \multicolumn{2}{|c|}{$\begin{array}{l}\text { Condensation } \\
\text { Condensation }\end{array}$} & & \\
\hline 19.1 & 46.8 & 3.8 & 6.8 & 248 & 301 & 350 & 25.6 \\
\hline
\end{tabular}

Aggregate: Natural sand (NS) with fineness modulus of 2.8 and apparent density of $2730 \mathrm{~kg} / \mathrm{m}^{3}$ was used. RS was obtained by crushing waste concrete from a highway in Shaanxi, with particle sizes of less than $4.75 \mathrm{~mm}$. Li [44] showed that the sulfate ion concentration of concrete reached a very high concentration at $110 \mathrm{~d}$ when concrete was 
immersed in $10 \% \mathrm{Na}_{2} \mathrm{SO}_{4}$ solution. Therefore, the $\mathrm{RS}$ was immersed in $2.4 \%, 5 \%$, and $8 \%$ $\mathrm{Na}_{2} \mathrm{SO}_{4}$ solution [45-47] for $120 \mathrm{~d}$ to simulate the RS carrying sulfate corrosion media. The $\mathrm{Na}_{2} \mathrm{SO}_{4}$ solution needed to be refreshed every $30 \mathrm{~d}$ in order to ensure a stable corrosive environment. The main physical properties of the aggregates are shown in Table 2.

Table 2. Physical properties of aggregates.

\begin{tabular}{ccccc}
\hline Aggregate Type & Porosity (\%) & $\begin{array}{c}\text { Bulk Density } \\
\left(\mathbf{k g} / \mathbf{m}^{\mathbf{3}}\right)\end{array}$ & $\begin{array}{c}\text { Water Absorption } \\
\mathbf{( \% )}\end{array}$ & $\begin{array}{c}\text { Crushing Index } \\
\mathbf{( \% )}\end{array}$ \\
\hline NS & 32.5 & 2730 & 1.13 & 7.8 \\
RS & 41.2 & 2510 & 4.63 & 15.2 \\
\hline
\end{tabular}

Blended materials: The blended materials were used to replace part of the cement in the mortar, including FA and GBFS. The proportion of FA incorporated into the mortar was constantly at $30 \%$ of the cement, whereas the amount of GBFS was 10\%. The chemical compositions of FA and GBFS are shown in Tables 3 and 4, respectively.

Table 3. Chemical compositions of FA.

\begin{tabular}{cccccccc}
\hline $\begin{array}{c}\text { Chemical } \\
\text { Compositions }\end{array}$ & $\mathrm{SiO}_{2}$ & $\mathrm{Al}_{2} \mathbf{O}_{3}$ & $\mathrm{CaO}$ & $\mathrm{Fe}_{2} \mathrm{O}_{3}$ & $\mathrm{~K}_{2} \mathbf{O}$ & $\mathrm{MgO}$ & $\mathrm{SO}_{3}$ \\
\hline Percentage (\%) & 50.35 & 33.18 & 0.63 & 6.39 & 0.86 & 1.15 & 1.03 \\
\hline
\end{tabular}

Table 4. Chemical compositions of GBFS.

\begin{tabular}{cccccccc}
\hline $\begin{array}{c}\text { Chemical } \\
\text { Compositions }\end{array}$ & $\mathrm{SiO}_{2}$ & $\mathrm{Al}_{2} \mathrm{O}_{3}$ & $\mathrm{CaO}$ & $\mathrm{Fe}_{2} \mathrm{O}_{3}$ & $\mathrm{~K}_{2} \mathrm{O}$ & $\mathrm{MgO}$ & $\mathrm{SO}_{3}$ \\
\hline Percentage (\%) & 32.5 & 13.50 & 41.90 & 0.80 & 0.60 & 6.9 & 1.83 \\
\hline
\end{tabular}

Admixture: The admixture selected for the mortar production was polycarboxylate superplasticizer (SP) with a proportion of $1.2 \%$ of the cement mass.

The mix composition of the mortar is shown in Table 5. The RS replacement rate group is marked as Group A, where A- 0 is the reference, Group B is the W/C ratio group, Group $C$ is the secondary cementitious material group, and group D was the RS corrosion concentration group. Detailed information of the prepared mortar samples is shown in Table 6.

Table 5. Mix proportions of mortar.

\begin{tabular}{ccccccccc}
\hline \multirow{2}{*}{ No. } & \multirow{2}{*}{$\begin{array}{c}\text { Replacement } \\
\text { Percentage (\%) }\end{array}$} & \multicolumn{7}{c}{ Design of Mix Proportion $\left(\mathbf{k g} / \mathbf{m}^{\mathbf{3}}\right)$} \\
\cline { 3 - 8 } & & Water & Cement & NS & RS & FA & GBFS & SP \\
\hline A-0 & 0 & 230 & 460 & 1128 & 0 & 0 & 0 & 5.5 \\
A-1 & 20 & 230 & 460 & 902 & 226 & 0 & 0 & 5.5 \\
A-2 & 50 & 230 & 460 & 564 & 564 & 0 & 0 & 5.5 \\
A-3 & 100 & 230 & 460 & 0 & 1128 & 0 & 0 & 5.5 \\
B-1 & 20 & 175 & 460 & 902 & 226 & 0 & 0 & 5.5 \\
B-2 & 20 & 202 & 460 & 902 & 226 & 0 & 0 & 5.5 \\
B-3 & 20 & 230 & 460 & 902 & 226 & 0 & 0 & 5.5 \\
C-1 & 20 & 230 & 460 & 902 & 226 & 0 & 0 & 5.5 \\
C-2 & 20 & 230 & 414 & 902 & 226 & 0 & 46 & 5.5 \\
C-3 & 20 & 230 & 322 & 902 & 226 & 138 & 0 & 5.5 \\
C-4 & 20 & 230 & 276 & 902 & 226 & 138 & 46 & 5.5 \\
D-1 & 20 & 230 & 460 & 902 & 226 & 0 & 0 & 5.5 \\
D-2 & 20 & 230 & 460 & 902 & 226 & 0 & 0 & 5.5 \\
D-3 & 20 & 230 & 460 & 902 & 226 & 0 & 0 & 5.5 \\
\hline
\end{tabular}


Table 6. Details of specimens for shrinkage tests.

\begin{tabular}{ccccc}
\hline No. & $\begin{array}{c}\text { Replacement } \\
\text { Percentage }\end{array}$ & W/C & Secondary Cementitious Materials & $\begin{array}{c}\text { Erosion } \\
\text { Concentration }\end{array}$ \\
\hline A-0 & $0 \%$ & 0.5 & C + NS & 0 \\
A-1 & $20 \%$ & 0.5 & C + NS + RS & $2.4 \%$ \\
A-2 & $50 \%$ & 0.5 & C + NS + RS & $2.4 \%$ \\
A-3 & $100 \%$ & 0.5 & C + NS + RS & $2.4 \%$ \\
B-1 & $20 \%$ & 0.38 & C + NS + RS & $5 \%$ \\
B-2 & $20 \%$ & 0.44 & C + NS + RS + RS & $5 \%$ \\
B-3 & $20 \%$ & 0.5 & C + NS + RS + 10\%GBFS & $5 \%$ \\
C-1 & $20 \%$ & 0.5 & C + NS + RS + 30\%FA & $5 \%$ \\
C-2 & $20 \%$ & 0.5 & C + NS + RS + 10\%GBFS + 30\%FA & $5 \%$ \\
C-3 & $20 \%$ & C + NS + RS & $5 \%$ \\
C-4 & $20 \%$ & C + NS + RS & $5 \%$ \\
D-1 & $20 \%$ & 0.5 & 0.5 & $2.4 \%$ \\
D-2 & $20 \%$ & 0.5 & $5 \%$ & $8 \%$ \\
D-3 & $20 \%$ & & \\
\hline
\end{tabular}

\subsection{Specimens}

A mold with a size of $25 \times 25 \times 280 \mathrm{~mm}$ (according to the Chinese Standard JCT6032004) was used to prepare the mortar specimens. Copper joints were inserted at the end of the mold before the mortar was poured into the mold. The mortar samples were prepared according to the requirements in Table 6 . Each group of six samples was prepared, three samples were prepared for the drying shrinkage, and the other three samples were used to measure the autogenous shrinkage. The average value of the results was taken.

\subsection{Testing Method}

\subsubsection{Drying and Autogenous Shrinkages of Mortar Tests}

The specimens were demolded after $24 \mathrm{~h}$, and the specimens tested for the drying shrinkage were cured to the age to be tested under the conditions of $20 \pm 1^{\circ} \mathrm{C}$ and a relative humidity of over $90 \%$. The specimens tested for the autogenous shrinkage were sealed with paraffin wax, wrapped with plastic immediately after demolding to prevent moisture loss, and then cured under the same curing conditions. The drying and autogenous shrinkage of the mortar were tested using a comparator following the Chinese standard JCT603-2004. The schematic diagram of the sample shrinkage test is shown in Figure 1 and the formula of the shrinkage of the mortar is given in Equation (1).

$$
\xi_{\mathrm{t}}=\frac{L_{0}-L_{t}}{L-L_{d}}
$$

where $\xi_{t}$ is the shrinkage value of the specimen at $\mathrm{t} d(\%) ; L_{0}$ is the initial length of the specimen (mm), which is the length of the specimen taken out from the mold $24 \mathrm{~h}$ after casting; $L$ is the length of specimen (mm), which is $280 \mathrm{~mm} ; L_{d}$ is the total length of the two copper joints inserted into the mortar, which is $20 \pm 2 \mathrm{~mm}$; and $L_{t}$ is the measured length of the specimen at $\mathrm{t} d(\mathrm{~mm})$.

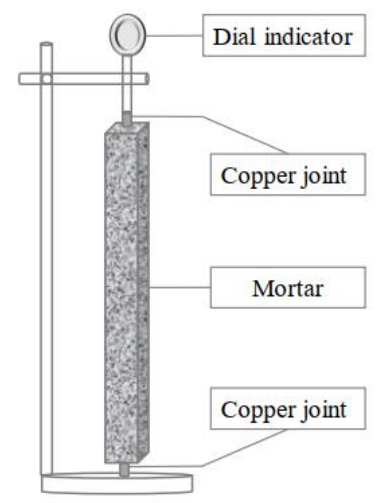

Figure 1. Example of the comparator. 


\subsubsection{SEM and XRD tests}

To view the surface morphology of reaction products of the mortar, JSM-6390A SEM (JEOL, Japan) was performed. The SEM specimens were prepared in the form of $1.5 \mathrm{~cm}$ cubes. Then, polishing and gold plating for $20 \mathrm{~min}$ for analysis.

The $\mathrm{XRD}$ (Shimadzu Corporation, Japan) analysis was conducted on the mortar powder dried at a temperature of $50{ }^{\circ} \mathrm{C}$ and sieved through a $75 \mu \mathrm{m}$ sieve. The tests were performed for $2 \theta=5-55^{\circ}$ in increments of $0.02^{\circ}$.

\section{Results and Discussion}

As regards shrinkage of recycled mortar specimens, Table 7 summarizes the average results of the shrinkage values, average, and standard deviation with the change of deformation behavior shown in Sections 3.1-3.4.

Table 7. The results of the shrinkage values, average, and standard deviation.

\begin{tabular}{|c|c|c|c|c|c|c|c|c|c|c|c|c|c|c|}
\hline & $t(d)$ & 1 & 3 & 5 & 9 & 14 & 28 & 56 & 90 & 120 & 150 & 180 & Average & $\begin{array}{l}\text { Standard } \\
\text { Deviation }\end{array}$ \\
\hline \multirow{14}{*}{$\begin{array}{c}\text { Drying } \\
\text { shrinkage } \\
\left(\times 10^{-6}\right)\end{array}$} & A-1 & 202 & 374 & 428 & 632 & 751 & 938 & 1062 & 1114 & 1141 & 1155 & 1173 & 815.45 & 356.82 \\
\hline & A-2 & 236 & 428 & 510 & 692 & 832 & 987 & 1136 & 1172 & 1203 & 1227 & 1242 & 878.64 & 362.16 \\
\hline & A-3 & 253 & 473 & 570 & 764 & 896 & 1044 & 1175 & 1226 & 1245 & 1274 & 1296 & 928.73 & 365.74 \\
\hline & A-4 & 324 & 564 & 718 & 872 & 1006 & 1136 & 1268 & 1331 & 1352 & 1374 & 1391 & 1030.55 & 367.33 \\
\hline & B-1 & 163 & 278 & 357 & 549 & 665 & 855 & 975 & 1032 & 1054 & 1074 & 1086 & 735.27 & 349.07 \\
\hline & B-2 & 190 & 322 & 405 & 616 & 724 & 901 & 1044 & 1088 & 1122 & 1135 & 1150 & 790.64 & 358.66 \\
\hline & B-3 & 221 & 402 & 488 & 667 & 787 & 948 & 1082 & 1141 & 1165 & 1192 & 1207 & 845.45 & 354.45 \\
\hline & C-1 & 221 & 402 & 488 & 667 & 787 & 948 & 1082 & 1141 & 1165 & 1192 & 1207 & 845.45 & 354.45 \\
\hline & C-2 & 126 & 294 & 391 & 565 & 688 & 856 & 963 & 1028 & 1057 & 1091 & 1107 & 742.36 & 351.50 \\
\hline & $C-3$ & 154 & 322 & 442 & 601 & 723 & 897 & 1014 & 1065 & 1108 & 1127 & 1144 & 781.55 & 355.15 \\
\hline & C-4 & 108 & 276 & 353 & 517 & 625 & 814 & 916 & 968 & 984 & 1022 & 1038 & 692.82 & 334.55 \\
\hline & D-1 & 236 & 428 & 510 & 692 & 832 & 987 & 1136 & 1172 & 1203 & 1227 & 1242 & 878.64 & 362.16 \\
\hline & D-2 & 221 & 402 & 488 & 667 & 787 & 948 & 1082 & 1141 & 1165 & 1192 & 1207 & 845.45 & 354.45 \\
\hline & D-3 & 203 & 387 & 432 & 621 & 756 & 911 & 1035 & 1083 & 1105 & 1127 & 1144 & 800.36 & 340.93 \\
\hline \multirow{14}{*}{$\begin{array}{c}\text { Autogenous } \\
\text { shrinkage } \\
\left(\times 10^{-6}\right)\end{array}$} & A-1 & 170 & 288 & 438 & 620 & 714 & 840 & 938 & 982 & 1020 & 1044 & 1075 & 739.00 & 320.36 \\
\hline & A-2 & 224 & 328 & 498 & 680 & 784 & 920 & 1012 & 1042 & 1075 & 1094 & 1128 & 798.64 & 323.72 \\
\hline & A-3 & 248 & 386 & 544 & 718 & 825 & 980 & 1062 & 1076 & 1117 & 1142 & 1175 & 843.00 & 326.18 \\
\hline & A-4 & 310 & 446 & 624 & 780 & 902 & 1042 & 1138 & 1157 & 1184 & 1203 & 1234 & 910.91 & 327.16 \\
\hline & B-1 & 321 & 407 & 540 & 724 & 816 & 971 & 1064 & 1091 & 1126 & 1148 & 1168 & 852.36 & 312.05 \\
\hline & B-2 & 272 & 352 & 468 & 681 & 754 & 926 & 1003 & 1048 & 1069 & 1098 & 1124 & 799.55 & 314.76 \\
\hline & B-3 & 210 & 311 & 456 & 638 & 715 & 873 & 948 & 987 & 1015 & 1048 & 1067 & 751.64 & 308.95 \\
\hline & C-1 & 210 & 311 & 456 & 638 & 715 & 873 & 948 & 987 & 1015 & 1048 & 1067 & 751.64 & 308.95 \\
\hline & C-2 & 40 & 208 & 414 & 572 & 660 & 806 & 889 & 915 & 951 & $\begin{array}{l}978 \\
978\end{array}$ & 1006 & 676.27 & 331.41 \\
\hline & $C-3$ & 208 & 404 & 582 & 696 & 816 & 978 & 1058 & 1082 & 1116 & 1134 & 1149 & 838.45 & 325.67 \\
\hline & C-4 & 138 & 370 & 538 & 670 & 770 & 918 & 997 & 1031 & 1065 & 1079 & 1107 & 789.36 & 325.08 \\
\hline & D-1 & 224 & 328 & 498 & 680 & 784 & 920 & 1012 & 1042 & 1075 & 1094 & 1128 & 798.64 & 323.72 \\
\hline & D-2 & 210 & 311 & 456 & 638 & 715 & 873 & 948 & 987 & 1015 & 1048 & 1067 & 751.64 & 308.95 \\
\hline & D-3 & 187 & 302 & 413 & 598 & 657 & 814 & 896 & 942 & 971 & 1001 & 1016 & 708.82 & 298.20 \\
\hline
\end{tabular}

\subsection{Effect of the RS Replacement Percentage on the Shrinkage of Mortar}

Figure 2 shows the effects of different RS replacement percentages on the shrinkage of the mortar. It can be seen from Figure 2 that both the drying and autogenous shrinkages of the mortar increase with an increase in the replacement percentage of RS; the shrinkage occurs significantly at the early age, and then tends to be slight after $60 \mathrm{~d}$. This was because the hydration reaction of the cement was relatively strong before the age of $28 \mathrm{~d}$, and the internal humidity decreased rapidly. As the curing age increased, the shrinkage of the mortar was inhibited by swelling corrosion products that were formed by the reaction of sulfate corrosion media carried by RS and the hydration products. As compared with the reference mortar, the drying shrinkage of the mortar with the RS replacement percentages of $20 \%, 50 \%$, and $100 \%$ increased by $14.4 \%, 26.5 \%$, and $50.8 \%$ at $3 \mathrm{~d}$, respectively, while the corresponding replacement percentage at $14 \mathrm{~d}$ increased by $10.8 \%, 19.3 \%$, and $34.0 \%$, respectively. The test results showed that an increase in drying shrinkage was more obvious when the replacement percentage of RS exceeded $50 \%$. This might be due to the porosity of RS also playing an important role in the amount of shrinkage increase [33,34]. When a humidity gradient between the recycled mortar and ambient was present, as the porosity of RS increased, the moisture loss in the cement paste also increased. Moreover, 
the incorporation of RS reduced the Young's modulus of recycled mortar, leading to greater shrinkage [48,49].

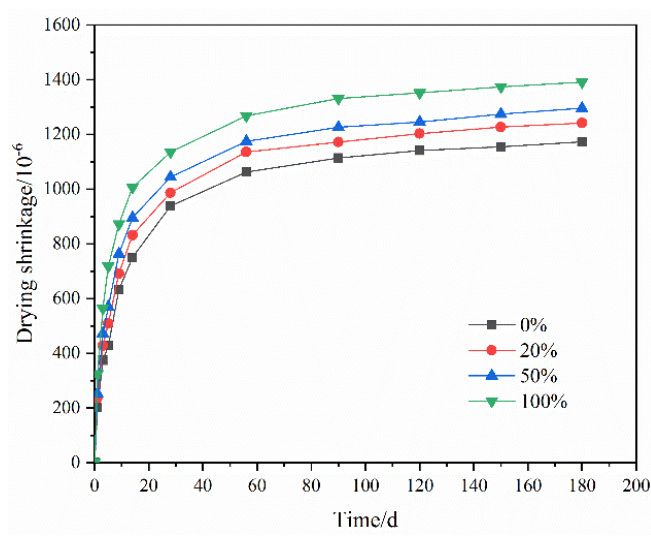

(a) Different RS replacement percentages

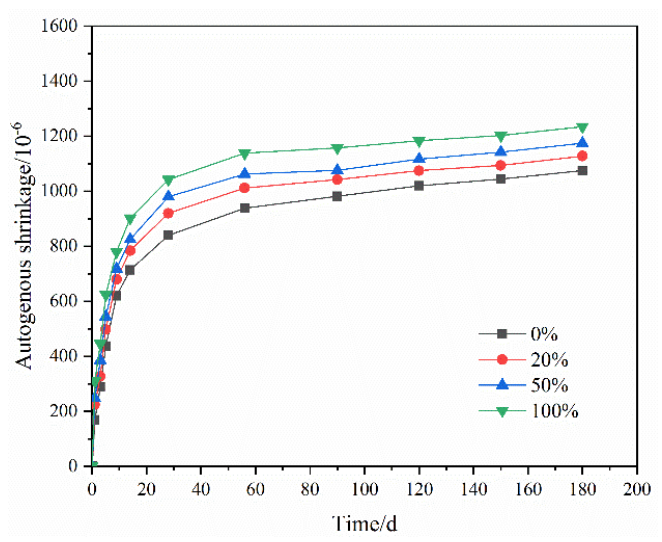

(b) Different RS replacement percentages

Figure 2. Effect of the RS replacement percentage on the shrinkage of mortar: (a) Drying shrinkage; (b) autogenous shrinkage.

\subsection{Effect of the W/C on the Shrinkage of Mortar}

The tests conducted, however, indicated that the $\mathrm{W} / \mathrm{C}$ ratio had a dominating effect on the shrinkage of mortar. As shown in Figure 3a, the drying shrinkage of the mortar increases with an increase in the W/C ratio, whereas in Figure $3 b$, the opposite trend is shown. Figure 3 a shows that a $\mathrm{W} / \mathrm{C}$ ratio of 0.5 is more affected than a $\mathrm{W} / \mathrm{C}$ ratio of 0.44 . The drying shrinkage of a $\mathrm{W} / \mathrm{C}$ ratio of 0.5 increased by $10.9 \%$ over that of a $\mathrm{W} / \mathrm{C}$ ratio of 0.38 , and the drying shrinkage of a $\mathrm{W} / \mathrm{C}$ ratio of 0.44 was $5.4 \%$ higher than that of a $\mathrm{W} / \mathrm{C}$ ratio of 0.38 at $28 \mathrm{~d}$. The larger the $\mathrm{W} / \mathrm{C}$ ratio, the larger the contact area of the mortar with water per unit volume, the more sufficient hydration reaction, and the more obvious drying shrinkage [50]. In contrast, the influence of the $\mathrm{W} / \mathrm{C}$ ratio on autogenous shrinkage was the opposite to that of drying shrinkage. The autogenous shrinkage of the mortar decreased with an increase in the W/C ratio, that is, the smaller the $\mathrm{W} / \mathrm{C}$ ratio, the more obvious the autogenous shrinkage phenomenon. Due to the early hydration reaction of the mortar being fast, the free moisture in the mortar was quickly consumed, and the remaining pores were occupied by unhydrated cement particles, which intensified the shrinkage of the mortar. As the age increased, the unhydrated cement particles continued to hydrate, which further consumed the pore moisture in the pores of the mortar, causing the mortar to continue to shrink during the initial setting and hardening process [51].

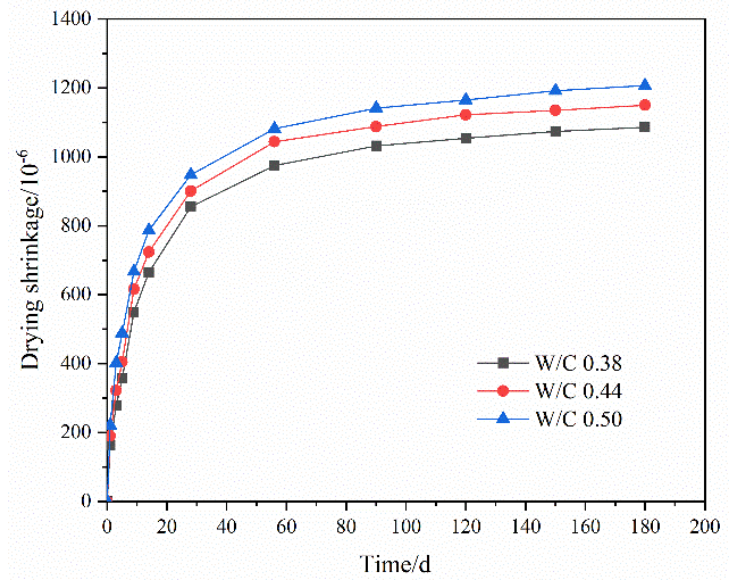

(a) Different $\mathrm{W} / \mathrm{C}$ ratio

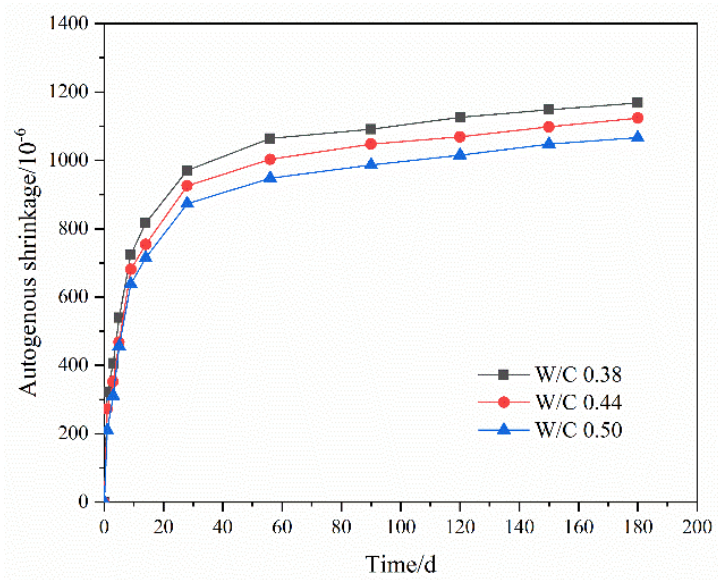

(b) Different $\mathrm{W} / \mathrm{C}$ ratio

Figure 3. Effect of the W/C on the shrinkage of mortar: (a) Drying shrinkage; (b) autogenous shrinkage. 


\subsection{Effect of the Secondary Cementitious Materials on the Shrinkage of Mortar}

Figure 4a compares the drying shrinkage of the mortar adding FA and GBFS. Although the addition of FA and GBFS both changed the drying shrinkage relative to the reference mortar, the effect of the addition of FA was much more significant, and shrinkage reduction was more obvious when considering mixes with FA and GBFS. This may stem from the fact that part of the cement was replaced by the secondary cementitious material, which reduced the amount of cement, thereby reducing the hydration rate of the mortar, slowing down the loss of moisture, and inhibiting the shrinkage deformation. This is consistent with the results of previous studies [34]. Furthermore, drying shrinkage might result from the refinement of pore structure due to which adhesive gels were formed by the reaction of the hydration product $\mathrm{Ca}(\mathrm{OH})_{2}$ with the blended materials.

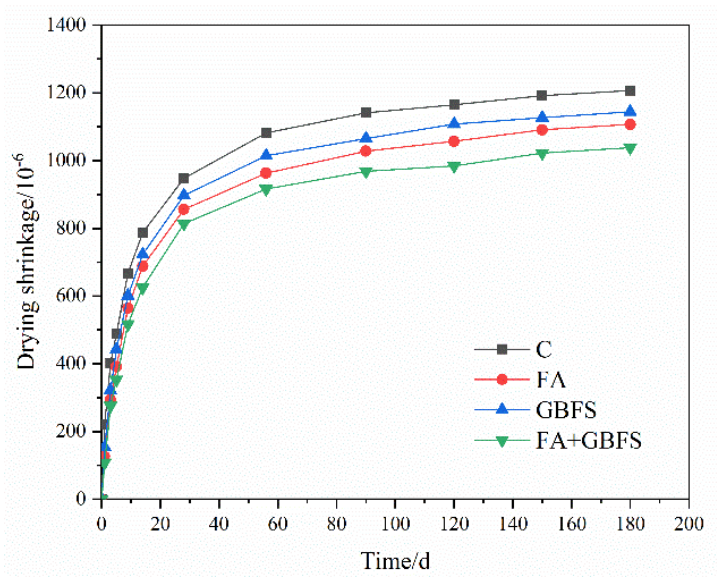

(a) Different blended materials

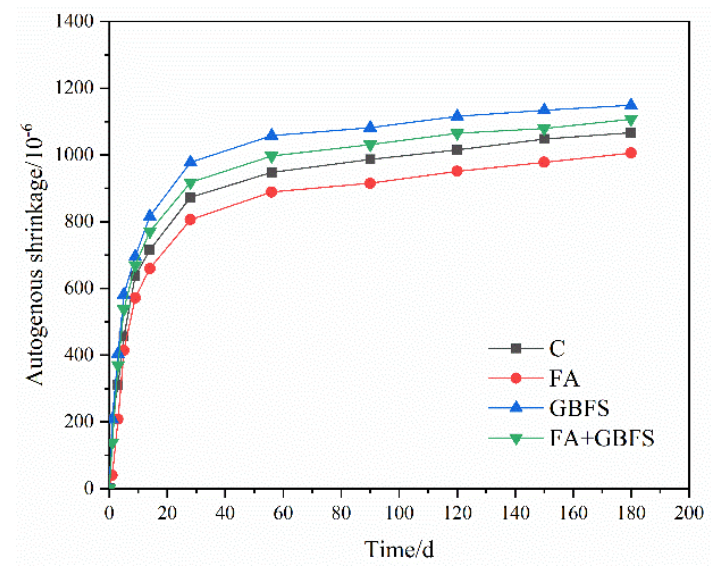

(b) Different blended materials

Figure 4. Effect of the blended materials on the shrinkage of mortar: (a) Drying shrinkage; (b) autogenous shrinkage.

Figure $4 \mathrm{~b}$ shows that FA has an inhibitory effect on the autogenous shrinkage of the mortar. This may be mainly due to the micro-aggregate filling effect of FA. The chemical shrinkage due to the active reaction of GBFS was higher than that of the cement hydration reaction, which caused the internal drying of the mortar to accelerate and the autogenous shrinkage to increase. However, since the activity of GBFS was better than that of FA, the autogenous shrinkage of mortar mixed with FA and GBFS was increased.

\subsection{Effect of the RS Corrosion Concentration on the Shrinkage of Mortar}

Figure 5 compares the drying and autogenous shrinkage of the mortar with different RS corrosion concentrations. The impact of the corrosion concentration of RS on the shrinkage of the mortar was quite limited and the shrinkage values of the shrinkage were almost similar. As compared with the value of the concentration of $2.4 \%$, the drying and autogenous shrinkage of the mortar at the concentrations of $5 \%$ and $8 \%$ decreased by $4.0 \%$, $7.7 \%, 5.1 \%$ and $16.2 \%$ at $28 \mathrm{~d}$, respectively. The corresponding decreases were $4.8 \%, 8.9 \%$, $6.3 \%$ and $11.5 \%$ at $56 \mathrm{~d}$, respectively. As the sulfate concentration increased, the shrinkage values of the mortar decreased slightly, possibly, because of the relationship, whereby the higher the corrosion concentration of RS, the more corrosion products produced. These expansive products filled up the pores, reduced the penetration of capillary pores, and hindered the diffusion and evaporation of moisture. In addition, these expansion products were equivalent to the expansion agent in the recycled mortar, and played a role in compensating for the shrinkage of recycled mortar. Therefore, as the degree of corrosion increased, the shrinkage values decreased. 


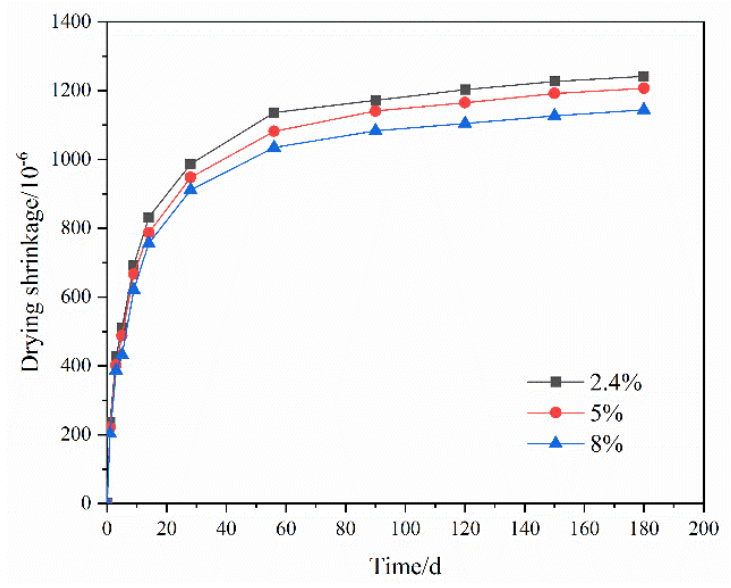

(a) Different RS corrosion concentrations

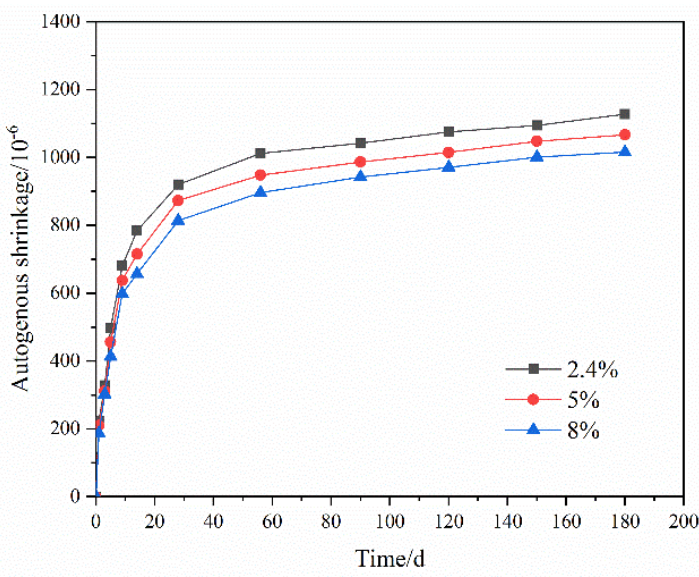

(b) Different RS corrosion concentrations

Figure 5. Effect of the RS erosion concentration on the shrinkage of mortar: (a) Drying shrinkage; (b) Autogenous shrinkage.

\subsection{XRD Analysis}

An XRD analysis was performed on the mortar specimens used for the drying shrinkage test. The results are shown in Figure 6. It can be seen that the reaction products mainly include $\mathrm{CSH}, \mathrm{CaCO}_{3}$, and quartz, and the expansive corrosion products mainly include ettringite and gypsum. The peak intensities of each reaction product were different due to the different compositions and mixing ratios of the test specimens. The specific analysis was as follows:

(1) Figure 6a shows that as the replacement percentage of RS increases, the peak intensities of ettringite and calcium hydroxide increase slightly. The recycled mortar with the replacement percentage of $100 \%$ was ettringite $\left(2 \theta\right.$ values at $9^{\circ}$ and $\left.32^{\circ}\right)$ peak intensity. An increase in the replacement percentage of RS would result in more defects in the internal structure of the mortar. At the same time, as the content of sulfate ions in the mortar increase, more corrosion products would be produced.

(2) Figure $6 \mathrm{~b}$ shows that the peak intensities of $\mathrm{Ca}(\mathrm{OH})_{2}$ increase in the following arrangement $(\mathrm{W} / \mathrm{C}=0.38,0.44,0.5)$ with two main peaks at $18^{\circ}$ and $34^{\circ}$ of $2 \theta$ values. The peak intensity of ettringite was correspondingly weakened. This showed that the internal structure of the mortar was denser under the condition of the lower $\mathrm{W} / \mathrm{C}$ ratio, thereby. slowing down the diffusion of sulfate ions [28].

(3) It is observed from Figure $6 \mathrm{c}$ that the peaks corresponding to CSH and ettringite of FA, GBFS, and FA + GBFS specimens become weaker as compared with the referent specimen. This indicated that the addition of FA and GBFS led to a significant reduction in calcium silicate phase and tricalcium aluminate phase in the mortar, while a decrease in calcium silicate phase caused a decrease in CSH gel, and a decrease in tricalcium aluminate phase reduced the formation of ettringite.

(4) Ettringite, $\mathrm{Ca}(\mathrm{OH})_{2}$, and gypsum are present in the mortar prepared with RS of different erosion concentrations, as presented in Figure 6d. The relative peak intensities of ettringite were slightly higher when the RS erosion concentration was $5 \%$ and $8 \%$. Generally, the appearance of the gypsum mineral phase was mainly formed by the reaction of sulfate ions with calcium hydroxide. Among the three specimens, the highest gypsum peak intensity $\left(2 \theta\right.$ value at $\left.12^{\circ}\right)$ was obtained for the specimen with a sulfate concentration of $8 \%$, indicating that the specimen had the highest sulfate solution concentration and the lowest concentration of reactive aluminum, thus, reaching the level of gypsum formation [52]. 


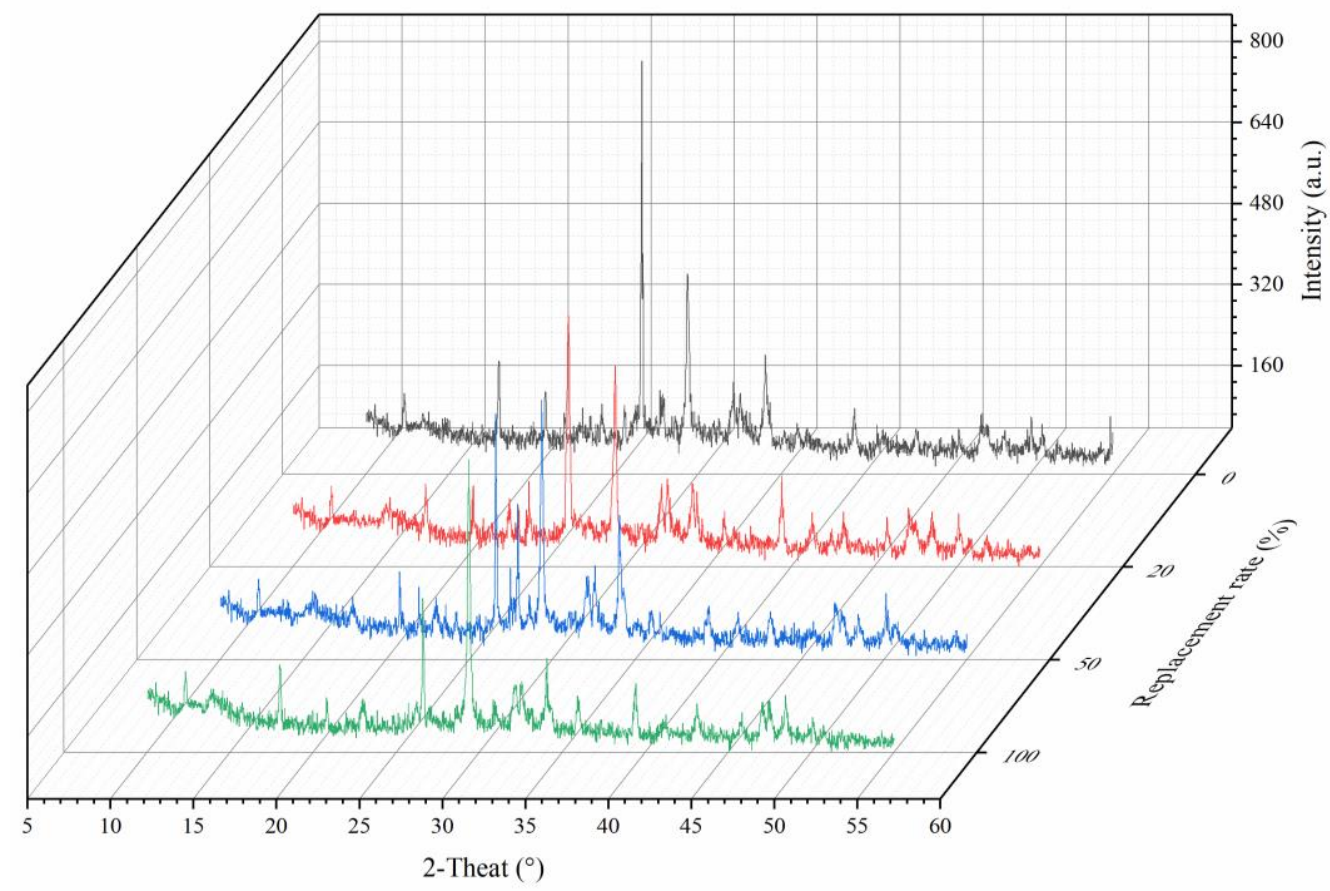

(a) The RS replacement percentage

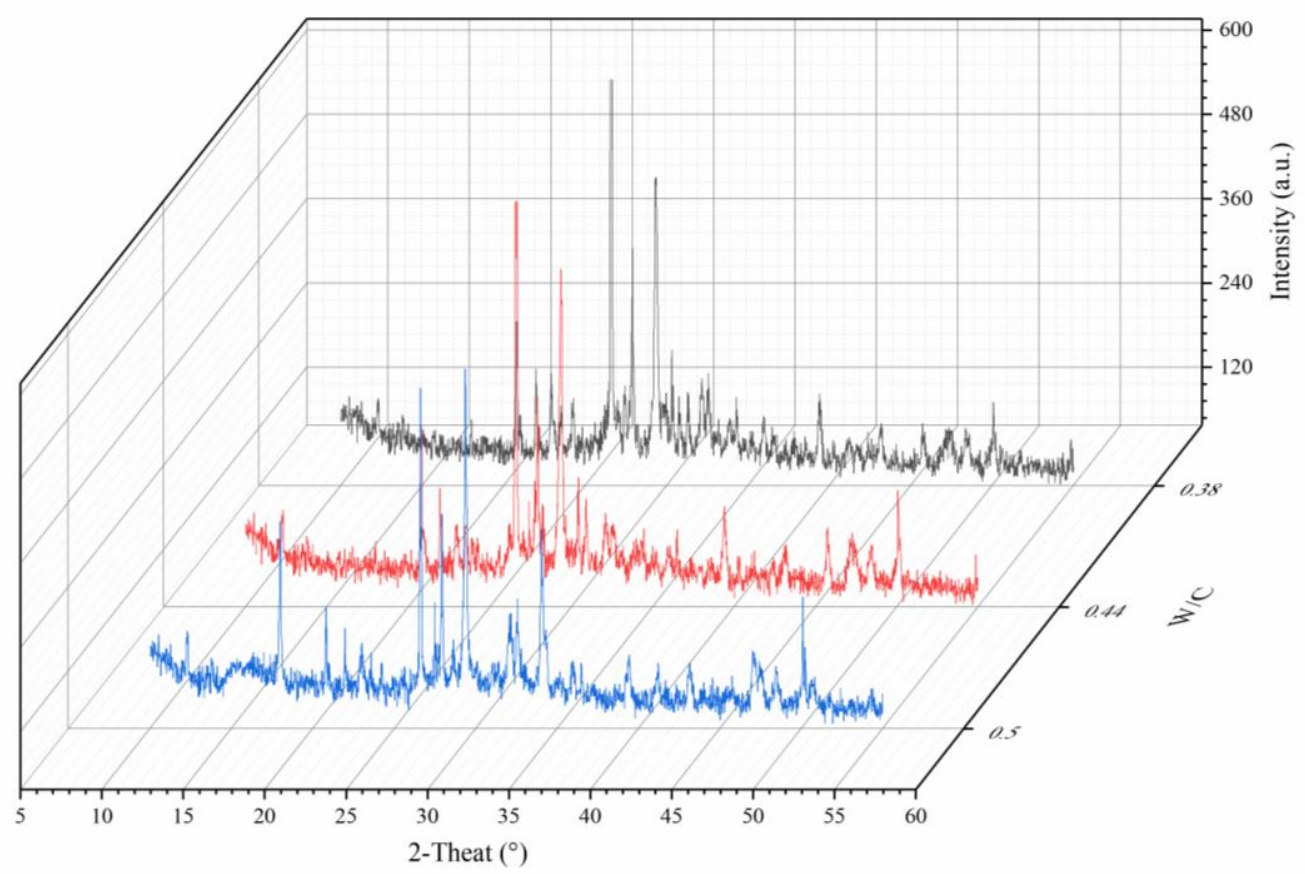

(b) The W/C ratio

Figure 6. Cont. 


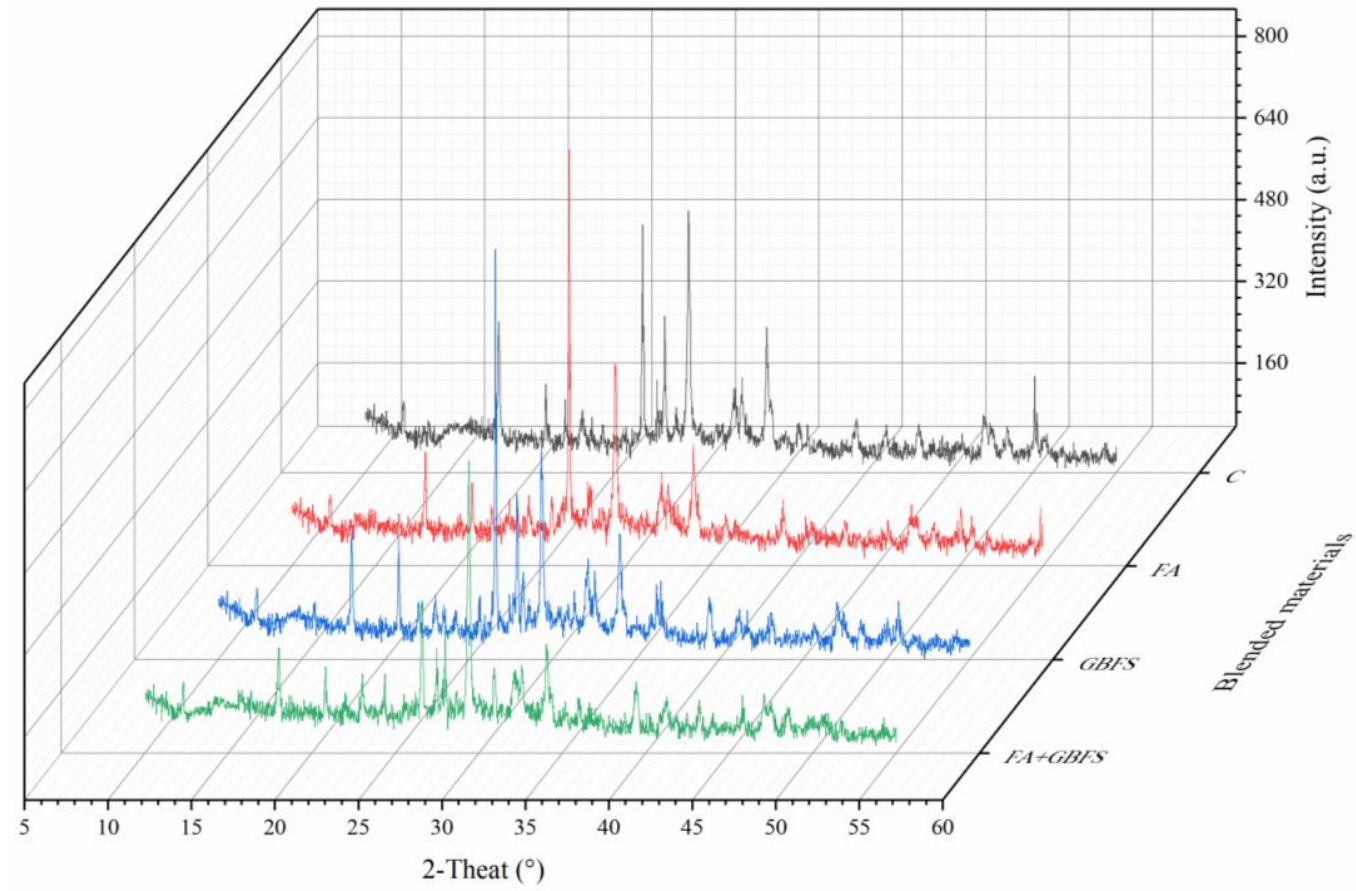

(c) The secondary cementitious materials

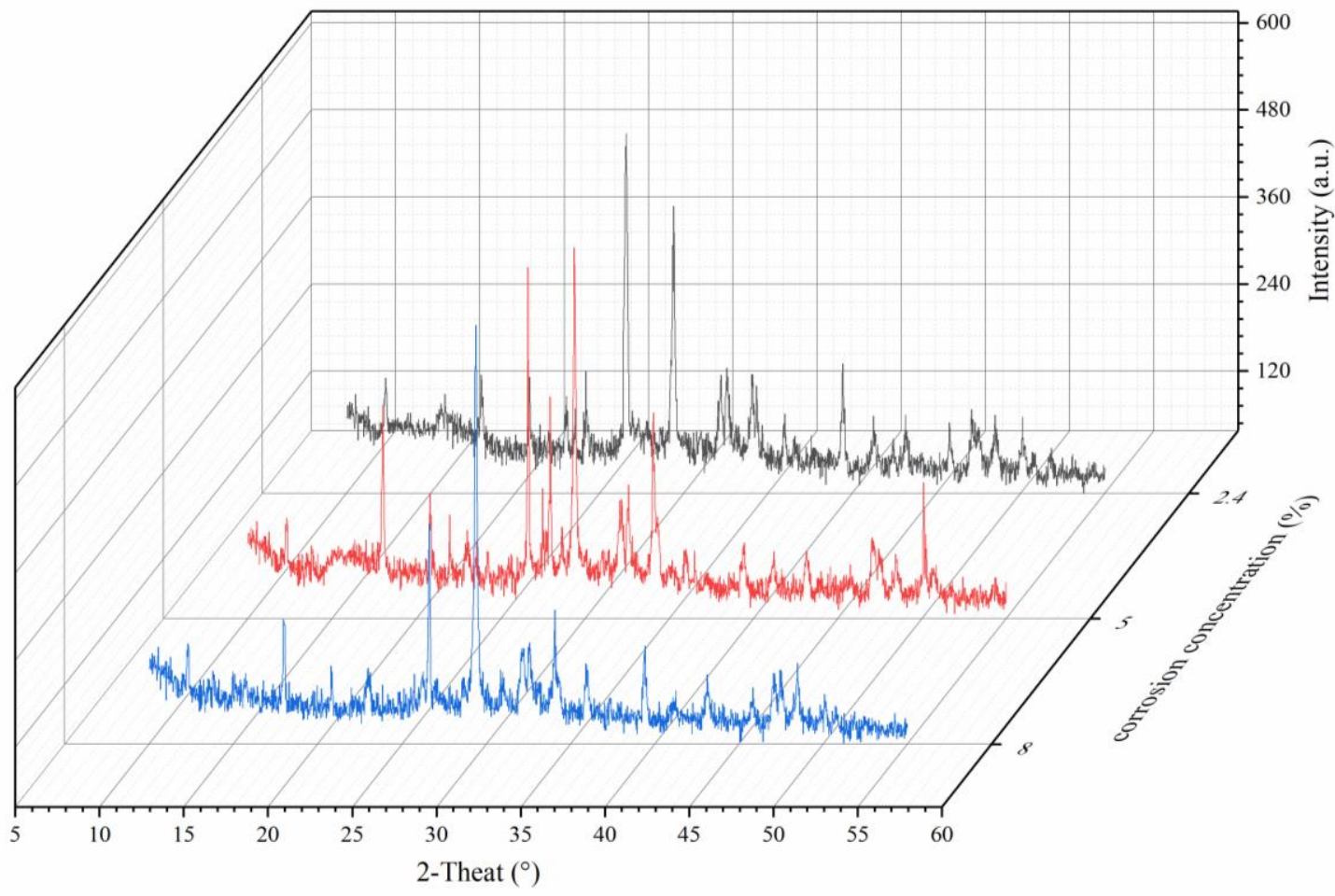

(d) The RS erosion concentration

Figure 6. XRD pattern of the mortar: (a) The RS replacement percentage; (b) The W/C ratio; (c) The secondary cementitious materials; (d) The RS erosion concentration.

\subsection{SEM Analysis}

The SEM micrographs were taken to study the microstructure of the mortar at different ages, as shown in Figure 7. The mortar parameters were a replacement percentage of RS of $20 \%$, a sulfate erosion concentration of $2.4 \%$, and a W/C ratio of 0.5 . Figure 7 a shows the presence of a large amount of CSH gel in the mortar at $7 \mathrm{~d}$. With increased curing age, 
ettringite with needle-shaped crystals and a small amount of gypsum with short columnar crystals appear, as shown in Figure $7 \mathrm{~b}$, and a large amount of gypsum with short columnar crystals existed at $56 \mathrm{~d}$ (Figure 7c). Figure $7 \mathrm{~d}$ shows the relative compact structure as compared with Figure 7c. The results were consistent with the XRD analysis.

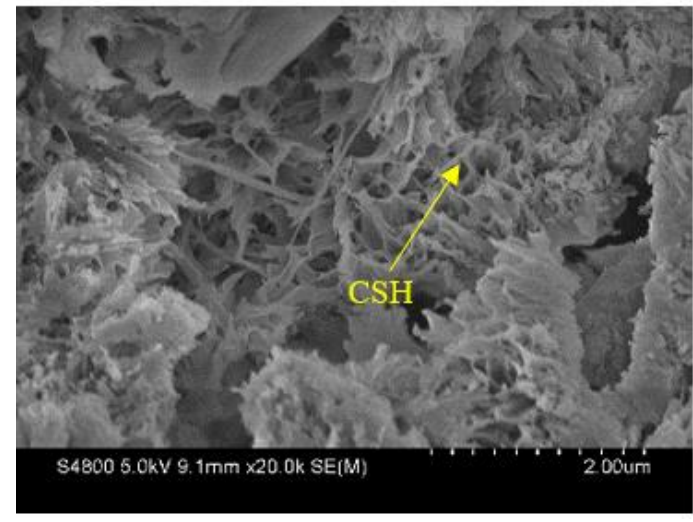

(a) SEM image of the mortar at $7 \mathrm{~d}$

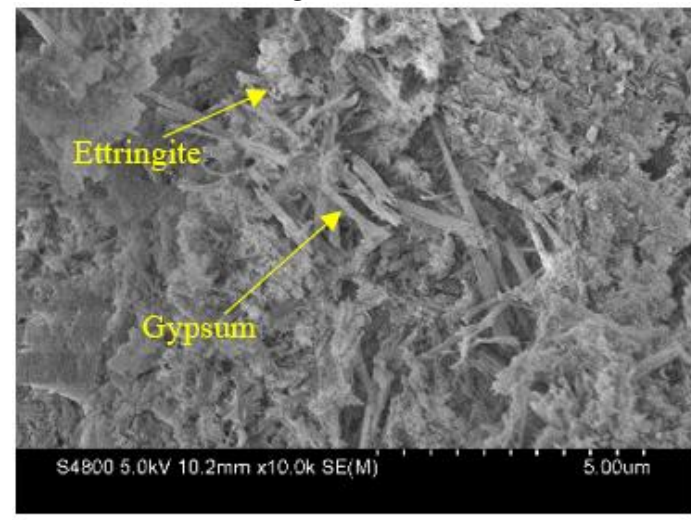

(c) SEM image of the mortar at $56 \mathrm{~d}$

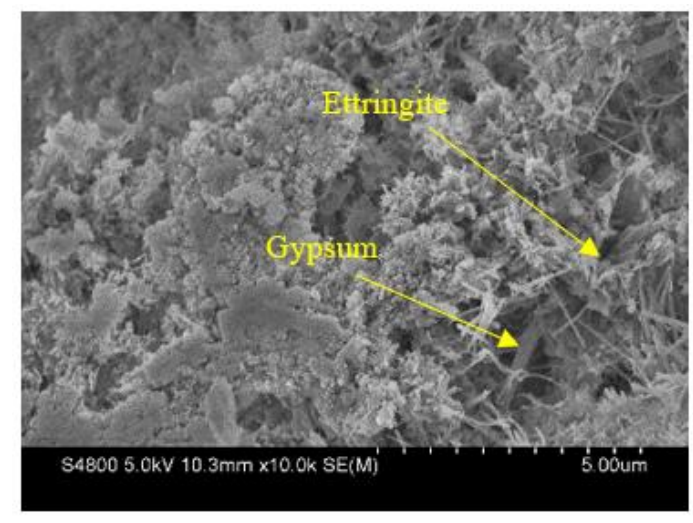

(b) SEM image of the mortar at $28 \mathrm{~d}$

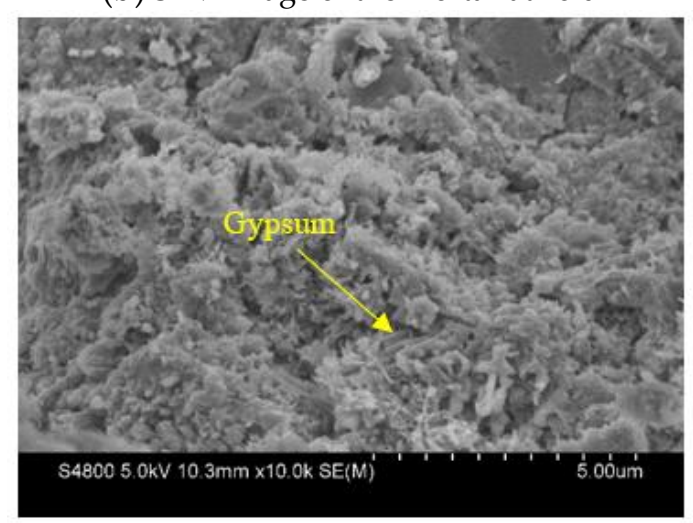

(d) SEM image of the mortar at $90 \mathrm{~d}$

Figure 7. SEM images of the mortar.

\section{Conclusions}

This study investigated the effect of RS carrying sulfate corrosion media on the drying and autogenous shrinkages of mortar. Four variables, namely, the replacement percentage of RS, W/C ratio, secondary cementitious material, and the corrosion concentration of RS, were considered. It is presented that:

(1) A comparison of different RS replacement percentages indicates that both the drying and autogenous shrinkages of the mortar increase with an increase in the RS replacement percentage, and the shrinkage values are significant early on, and then, later, tend to decrease slightly.

(2) The $\mathrm{W} / \mathrm{C}$ ratio is positively correlated with drying shrinkage, while it is negatively correlated with autogenous shrinkage. The drying and autogenous shrinkages occur significantly at early ages.

(3) The addition of FA has a significant inhibitory effect on the drying and autogenous shrinkages of the mortar. The drying shrinkage of the mortar is reduced, while the autogenous shrinkage is increased by adding GBFS. The addition of FA and GBFS cause an increase in the autogenous shrinkage, which is due to the fact that the activity of GBFS is better than that of FA.

(4) The drying and autogenous shrinkages of the mortar decrease slightly with an increase in the RS corrosion concentration. This is because the higher the corrosion concen- 
tration of RS, the more corrosion products are produced, which fills the internal pores of the mortar.

(5) SEM and XRD analyses are performed to investigate the corrosion products and microstructure of the mortar matrix. The results show that the sulfate ions carried by RS react with the cement hydration products to generate expansive corrosion products, which fill the internal pores of the mortar and slow down the shrinkage.

Author Contributions: Conceptualization, Y.T.; methodology, X.Y.; validation, X.Y., J.J. and M.Z.; resources, X.L.; data curation, M.Z.; writing—original draft preparation, X.Y.; writing—review and editing, J.J.; project administration, Y.T. and L.Q. All authors have read and agreed to the published version of the manuscript.

Funding: This research was funded by the National Natural Science Foundation of China, grant number 51878065; the Fundamental Research Funds for the Central Universities, CHD, grant number 300102319201; the Natural Science Foundation of Shaanxi Province of China, grant number 2017JM5030; the State Key Laboratory of High Performance Civil Engineering Materials, grant number 2018CEM010, and the Scientific research project of Shaanxi Provincial Department of Science and Technology, grant number 2021KJXX-80.

Data Availability Statement: Data is contained within the article. The data presented in this study are available in Table 7.

Conflicts of Interest: The authors declare no conflict of interest.

\section{References}

1. Development Status Analysis and Market Forecast Forecast Report of China's Construction Waste Treatment Industry from 2019 to China Industry Research; China Industry Research: Beijing, China, 2019.

2. Lotfi, S.; Eggimann, M.; Wagner, E.; Mróz, R.; Deja, J. Performance of recycled aggregate concrete based on a new concrete recycling technology. Constr. Build. Mater. 2015, 95, 243-256. [CrossRef]

3. Wang, L.; Wang, J.; Qian, X.; Chen, P.; Xu, Y.; Guo, J. An environmentally friendly method to improve the quality of recycled concrete aggregates. Constr. Build. Mater. 2017, 144, 432-441. [CrossRef]

4. Bravo, M.; De Brito, J.; Pontes, J.; Evangelista, L. Durability performance of concrete with recycled aggregates from construction and demolition waste plants. Constr. Build. Mater. 2015, 77, 357-369. [CrossRef]

5. Silva, R.V.; De Brito, J.; Dhir, R.K. Properties and composition of recycled aggregates from construction and demolition waste suitable for concrete production. Constr. Build. Mater. 2014, 65, 201-217. [CrossRef]

6. Katz, A. Properties of concrete made with recycled aggregate from partially hydrated old concrete. Cem. Concr. Res. 2003, 33, 703-711. [CrossRef]

7. Martín-Morales, M.; Zamorano, M.; Ruiz-Moyano, A.; Valverde-Espinosa, I. Characterization of recycled aggregates construction and demolition waste for concrete production following the Spanish Structural Concrete Code EHE-08. Constr. Build. Mater. 2011, 25, 742-748. [CrossRef]

8. Akbarnezhad, A.; Ong, K.; Zhang, M.; Tam, C.; Foo, T. Microwave-assisted beneficiation of recycled concrete aggregates. Constr. Build. Mater. 2011, 25, 3469-3479. [CrossRef]

9. Ismail, S.; Ramli, M. Engineering properties of treated recycled concrete aggregate (RCA) for structural applications. Constr. Build. Mater. 2013, 44, 464-476. [CrossRef]

10. Kou, S.-C.; Poon, C.S. Properties of concrete prepared with PVA-impregnated recycled concrete aggregates. Cem. Concr. Compos. 2010, 32, 649-654. [CrossRef]

11. Qiu, J.; Tng, D.Q.S.; Yang, E.-H. Surface treatment of recycled concrete aggregates through microbial carbonate precipitation. Constr. Build. Mater. 2014, 57, 144-150. [CrossRef]

12. Singh, L.P.; Bisht, V.; Aswathy, M.S.; Chaurasia, L.; Gupta, S. Studies on performance enhancement of recycled aggregate by incorporating bio and nano materials. Constr. Build. Mater. 2018, 181, 217-226. [CrossRef]

13. Xie, J.H.; Guo, Y.C.; Liu, L.S.; Xie, Z.H. Compressive and flexural behaviours of a new steel-fibre-reinforced recycled aggregate concrete with crumb rubber. Constr. Build. Mater. 2015, 15, 263-272. [CrossRef]

14. Kou, S.-C.; Poon, C.S. Effect of the quality of parent concrete on the properties of high performance recycled aggregate concrete. Constr. Build. Mater. 2015, 77, 501-508. [CrossRef]

15. McGinnis, M.J.; Davis, M.; de la Rosa, A.; Weldon, B.D.; Kurama, Y.C. Strength and stiffness of concrete with recycled concrete aggregates. Constr. Build. Mater. 2017, 154, 258-269. [CrossRef]

16. Pedro, D.; de Brito, J.; Evangelista, L. Structural concrete with simultaneous incorporation of fine and coarse recycled concrete aggregates: Mechanical, durability and long-term properties. Constr. Build. Mater. 2017, 154, 294-309. [CrossRef]

17. Xiao, J.; Li, L.; Shen, L.; Poon, C.S. Compressive behaviour of recycled aggregate concrete under impact loading. Cem. Concr. Res. 2015, 71, 46-55. [CrossRef] 
18. Paz, S.S.; González-Fonteboa, B.; Martínez-Abella, F.; Eiras-López, J. Flexural performance of reinforced concrete beams made with recycled concrete coarse aggregate. Eng. Struct. 2018, 156, 32-45. [CrossRef]

19. Pedro, D.; de Brito, J.; Evangelista, L. Influence of the use of recycled concrete aggregates from different sources on structural concrete. Constr. Build. Mater. 2014, 71, 141-151. [CrossRef]

20. Zega, C.; Dos Santos, G.C.; Villagrán-Zaccardi, Y.; Di Maio, A. Performance of recycled concretes exposed to sulphate soil for 10 years. Constr. Build. Mater. 2016, 102, 714-721. [CrossRef]

21. Bui, N.K.; Satomi, T.; Takahashi, H. Mechanical properties of concrete containing $100 \%$ treated coarse recycled concrete aggregate. Constr. Build. Mater. 2018, 163, 496-507. [CrossRef]

22. Tam, V.W.Y.; Tam, C.M.; Le, K.N. Removal of cement mortar remains from recycled aggregate using pre-soaking approaches Resour. Conserv. Recycl. 2007, 50, 82-101. [CrossRef]

23. Bui, N.K.; Satomi, T.; Takahashi, H. Improvement of mechanical properties of recycled aggregate concrete basing on a new combination method between recycled aggregate and natural aggregate. Constr. Build. Mater. 2017, 148, 376-385. [CrossRef]

24. Xuan, D.; Zhan, B.; Poon, C.S. Assessment of mechanical properties of concrete incorporating carbonated recycled concrete aggregates. Cem. Concr. Compos. 2016, 65, 67-74. [CrossRef]

25. Bravo, M.; de Brito, J.; Evangelista, L.; Pacheco, J. Durability and shrinkage of concrete with CDW as recycled aggregates: Benefits from superplasticizer's incorporation and influence of CDW composition. Constr. Build. Mater. 2018, 168, 818-830. [CrossRef]

26. Pedro, D.; de Brito, J.; Evangelista, L. Evaluation of high-performance concrete with recycled aggregates: Use of densified silica fume as cement replacement. Constr. Build. Mater. 2017, 147, 803-814. [CrossRef]

27. Bendimerad, A.Z.; Rozière, E.; Loukili, A. Plastic shrinkage and cracking risk of recycled aggregates concrete. Constr. Build. Mater. 2016, 121, 733-745. [CrossRef]

28. Tian, Y.; Yan, X.; Zhang, M.; Lu, D.; Yang, T.; Wang, Z.; Li, W. Internal transport and corrosion behaviors of sulfate corrosion media carried by recycled aggregate in concrete. Constr. Build. Mater. 2020, 260, 120480. [CrossRef]

29. Paz, S.S.; González-Fonteboa, B.; Martínez-Abella, F.; González-Taboada, I. Time-dependent behaviour of structural concrete made with recycled coarse aggregates. Creep Shrinkage. Constr. Build. Mater. 2016, 122, 95-109. [CrossRef]

30. Zhang, H.; Wang, Y.-Y.; Lehman, D.E.; Geng, Y. Autogenous-shrinkage model for concrete with coarse and fine recycled aggregate. Cem. Concr. Compos. 2020, 111, 103600. [CrossRef]

31. Domingo-Cabo, A.; Lázaro, C.; López-Gayarre, F.; Serrano-López, M.A.; Serna, P.; Castaño-Tabares, J.O. Creep and shrinkage of recycled aggregate concrete. Constr. Build. Mater. 2009, 23, 2545-2553. [CrossRef]

32. Domingo, A.; Lázaro, C.; Gayarre, F.L.; Serrano, M.A.; López-Colina, C. Long term deformations by creep and shrinkage in recycled aggregate concrete. Mater. Struct. 2009, 43, 1147-1160. [CrossRef]

33. Gómez Soberón, J.M.V. Sinkage of concrete with replacement of aggregate with recycled concrete aggregate. In Proceedings of the ACI Fifth International Conference on Innovations in Design with Emphasis on Seismic, Wind, and Environmental Loading; Quality Control and Innovations in Materials/Hot Weather Concreting, Cancun, Mexico, 1 January 2002; Available online: http: / / hdl.handle.net/2117/2559 (accessed on 16 September 2021).

34. Gonzalez-Corominas, A.; Etxeberria, M. Effects of using recycled concrete aggregates on the shrinkage of high performance concrete. Constr. Build. Mater. 2016, 115, 32-41. [CrossRef]

35. Gholampour, A.; Ozbakkaloglu, T. Time-dependent and long-term mechanical properties of concretes incorporating different grades of coarse recycled concrete aggregates. Eng. Struct. 2018, 157, 224-234. [CrossRef]

36. Rao, G. Long-term drying shrinkage of mortar-Influence of silica fume and size of fine aggregate. Cem. Concr. Res. 2001, 31, 171-175. [CrossRef]

37. Nežerka, V.; Havlásek, P.; Trejbal, J. Mitigating inclusion-induced shrinkage cracking in cementitious composites by incorporating recycled concrete fines. Constr. Build. Mater. 2020, 248, 118673. [CrossRef]

38. Shariq, M.; Prasad, J.; Abbas, H. Creep and drying shrinkage of concrete containing GGBFS. Cem. Concr. Compos. 2016, 68, 35-45. [CrossRef]

39. Yousefieh, N.; Joshaghani, A.; Hajibandeh, E.; Shekarchizadeh, M. Influence of fibers on drying shrinkage in restrained concrete. Constr. Build. Mater. 2017, 148, 833-845. [CrossRef]

40. Shen, D.; Wen, C.; Zhu, P.; Wu, Y.; Yuan, J. Influence of Barchip fiber on early-age autogenous shrinkage of high strength concrete. Constr. Build. Mater. 2020, 256, 119223. [CrossRef]

41. Saiz-Martínez, P.; Ferrández-Vega, D.; Morón-Fernández, C.; De Tejada-Alonso, A.P. Comparative study of the influence of three types of fibre in the shrinkage of recycled mortar. Mater. Construcción 2018, 68, 168. [CrossRef]

42. Kanema, J.M.; Eid, J.; Taibi, S. Shrinkage of earth concrete amended with recycled aggregates and superplasticizer: Impact on mechanical properties and cracks. Mater. Des. 2016, 109, 378-389. [CrossRef]

43. Souche, J.-C.; Bendimerad, A.Z.; Roziere, E.; Salgues, M.; Devillers, P.; Garcia-Diaz, E.; Loukili, A. Early age behaviour of recycled concrete aggregates under normal and severe drying conditions. J. Build. Eng. 2017, 13, 244-253. [CrossRef]

44. Li, T.; Zhu, P.T.; Zhang, B.; Ding, K.L.; Sun, Z.M. Experimental study on corrosion rection-diffusion process of concrete under sulfate attack. Bull. Chin. Ceram. Soc. 2020, 39, 50-55. [CrossRef]

45. Bulatović, V.; Melešev, M.; Radeka, M.; Radonjanin, V.; Lukić, I. Evaluation of sulfate resistance of concrete with recycled and natural aggregates. Constr. Build. Mater. 2017, 152, 614-631. [CrossRef] 
46. GB/T 50082-Standard for Test Methods of Long-Term Performance and Durability of Ordinary Concrete; Ministry of Housing and Urban-Rural Development: Beijing, China, 2009.

47. Liu, T.; Qin, S.; Zou, D.; Song, W. Experimental investigation on the durability performances of concrete using cathode ray tube glass as fine aggregate under chloride ion penetration or sulfate attack. Constr. Build. Mater. 2018, 163, 634-642. [CrossRef]

48. Butler, L.; West, J.S.; Tighe, S.L. Effect of recycled concrete coarse aggregate from multiple sources on the hardened properties of concrete with equivalent compressive strength. Constr. Build. Mater. 2013, 47, 1292-1301. [CrossRef]

49. Dapena, E.; Alaejos, P.; Lobet, A.; Pérez, D. Effect of recycled sand content on characteristics of mortars and concretes. J. Mater. Civ. Eng. 2011, 23, 414-422. [CrossRef]

50. Liao, Y. Chemical shrinkage and electrical resistivity of cement at early age. J. Huazhong Univ. Sci. Technol. 2012, 40, 29-33.

51. Ming, A.N.; Zhu, J.; Qin, W. Autogenous shrinkage of high performance concrete. J. Build. Mater. 2001, 4, 159-166.

52. Bellmann, F.; Möser, B.; Stark, J. Influence of sulfate solution concentration on the formation of gypsum in sulfate resistance test specimen. Cem. Concr. Res. 2006, 36, 358-363. [CrossRef] 